\title{
A RAINHA SANTA E A CORTE DOS MISERÁVEIS: CARIDADE E PODER NA BAIXA IDADE MÉDIA PORTUGUESA.
}

\author{
Georgina Silva dos Santos*
}

\section{Resumo}

A Baixa Idade Média Portuguesa concedeu à caridade um papel significativo na afirmação do poder régio. Com base na prédica mendicante e na imagem mariana, referências caras às devoções populares, a monarquia dionisina prescreveu um modelo de atuação para a primeira dama do paço. Cristalizando o papel de intercessora, o de "advogada dos pobres", D. Isabel de Aragão recebeu um lugar cativo na tradição oral. Descrita como uma Rainha devota e caridosa, como uma Santa capaz de realizar milagres, a senhora do paço maquiou as diferenças sociais com esmolas e doações demarcando o papel da rainha no imaginário político português.

Palavras-chaves: Portugal; rainha; caridade.

A emergência de uma postura religiosa atenta ao mundo onde a moeda tornava-se um meio de fazer crescer o poderio daqueles que a detinham e, sobretudo, punha em evidência aqueles que dela estavam privados, impingiu aos poderes temporais do século XIII uma atitude distinta diante da pobreza.

Perante um quadro econômico que imputava, paulatinamente, ao espaço urbano uma função significativa, a cidade tornou-se um palco onde os dramas humanos oscilavam entre a prosperidade e a infelicidade, pois se exibia a vistosa morada dos "graúdos", enriquecidos e endinhei-

*Professora Assistente do Departamento de História da UFG.

História Revista, 5(1/2): 89-109, jan./dez, 2000 
rados, era também refúgio de intempéries e calamidades climáticas que atingiam, sobretudo, o viver dos "miúdos" marcados pela pobreza laboriosa.

Distantes das comitivas reais, dos tecidos reluzentes vindos do exterior, encontrava-se a cuia do pedinte, o roto e o esfarrapado. Aos olhos de qualquer mortal oferecia-se uma discrepância social, cujo espectro incluía o mercador, o banqueiro, o modesto artesão-lojista, mas também o cego menestrel, o camponês sem propriedade e o clérigo mendicante, todos regulados pelo movimento pendular "da bolsa e da vida", pelo som grave dos sinos comunais.

Cúmplices da alteração das estruturas, de práticas econômicas sujeitas à flutuação dos preços, por vezes, vítimas do ardiloso talento dos comerciantes capazes de prever com mais precisão os períodos oportunos para a compra e revenda de gêneros, homens e mulheres conviveram, na viragem dos séculos XIII e XIV, com uma dimensão temporal multifacetada. Testemunhas de um conflito entre o tempo canônico, guiado pela liturgia, e o tempo do mercador, submetido às surpresas meteorológicas, ao ciclo das estações e aos cataclismos naturais, os grupos sociais conviveram com apreensões temporais distintas, mas não excludentes.

Sujeitos ao incansável ir e vir do sol e da lua, à duração de suas jornadas de trabalho, aos momentos íntimos e manifestos de devoção e adoração do Deus-Pai, os filhos deste Tempo operaram, simultaneamente, com o tempo sobrenatural, marcado pela expectativa da salvação, e a progressiva racionalização dos tempos natural e profissional. "Esta inflexão decisiva nas mentalidades coletivas" (LE GoFf, 1980, p. 56) provocou uma reorientação nos instrumentos de penitência, caridade, santidade, e, por outro lado, um recrudescimento na condenação da usura.

Ponto de transição entre as atividades lícitas e ilícitas, denominador de um conjunto de práticas financeiras proibidas, a usura, em companhia de seis outros pecados capitais, era enfaticamente execrada pela doutrina eclesiástica. Distinta do lucro oriundo da produção ou da troca de bens materiais, caracterizada pelo ganho de juros extraídos sobre o empréstimo em dinheiro, combatida pela Sagrada Escritura e pelos Padres da Igreja, esta fórmula de acumulação monetária tornou-se um item importante nas regulamentações do Direito Canônico quando o tempo do mercador foi de encontro ao tempo de Deus. 
Por não observar o calendário da Igreja, por trabalhar sem guardar os dias do Senhor, por sua ânsia em multiplicar o que na raiz era impuro e se apropriar do tempo que só ao Criador pertencia, o usurário, inimigo da justiça, símbolo da indolência e da avareza, era amaldiçoado e entregue às chamas de Satanás. Esta postura severa não era, todavia, uma inovação do trezentos.

Ladeado pelos estalajadeiros, açougueiros, jograis, mágicos, soldados, prostitutas, moleiros, tripeiros, personagens fáceis nas ruas e arrabaldes da cidade, os usurários figuraram desde a Alta Idade Média entre as profissões indignas, transgressoras. Se alguns eram violadores dos tabus do sangue, da impureza ou favoreciam a luxúria e a licenciosidade, os usurários infringiam o tabu do dinheiro (idem, 1989, p. 47).

A Baixa Idade Média, no entanto, trouxe à cena urbana as marcações precisas deste elenco de atores sociais. Sorrateiramente, o exercício destas habilitações foi sendo recuperado em decorrência do novo quadro econômico. Escondido sob os trajes do mercador, o usurário assumia então uma outra face. Mas é certo que nem por isso a Igreja baixou suas armas e deu-lhe paz. O sermão modelo do eminente Jacques de Vitry, cônego regular e depois bispo, lançava-os no mundo sob a guarda do diabo. Situados à periferia do esquema trifuncional da sociedade medieval, diferenciados dos oratores, belatores e laboratores por "não serem úteis e produtivos" ( $i b i d$, p. 56-57), por estarem a serviço de um verme capaz de necrosar o tecido social, seu ganho era tido como improdutivo e nefasto.

Vestígio que ilumina a acomodação do instrumental mental ao circuito comercial que tomou conta da Europa, desde o Mar do Norte às bainhas do Mediterrâneo, esse discurso aponta também para o receio e a desconfiança dos clérigos diante dos desdobramentos das práticas econômicas emergentes, particularmente, pela sedução que a usura exercia sobre os menos afortunados, quer pelo endividamento, quer pelo convite à deserção dos campos e a proliferação do germe da usura em detrimento do trabalho honesto e lícito. (ibid, p. 25)

A roda da fortuna, porém, não girou somente a favor do pecado. Desta feita, assim como o passado havia justificado o orgulho do cavaleiro santificando o uso da espada, o presente fazia santo o uso do dinheiro quando adjunto aos atos enobrecedores da caridade (MolLAT, 1989, 
p. 150). Apregoada pelas Ordens Mendicantes, encorajada pelo temor da morte e de uma vida pouco confortável ao espírito no além-túmulo, a primeira entre as três virtudes teologais descritas por São Paulo partiu dos portões altos e frios dos mosteiros, deixando sua concepção puramente ritualizada, para ganhar ação na esfera dos laicos. Neste circuito, o estatuto "conceitual e místico" outrora conferido aos pauperes Christi perdeu sua conotação social. (ibid., p. 111).

Por esses dias, a legislação dos sínodos e dos conselhos do clero encorajava os fiéis a legar após a morte a "parte do pobre" (ibid., p. 149). Se a tempo e a hora dos lava-pés e da esporádica distribuição de pães na soleira dos oratores pensava-se em socorrer da miséria as viúvas e órfãos, quando o relógio comunal tornou-se ponto de encontro, os mesmos a provar da hóstia e do vinho consagrados buscavam o atendimento aos enfermos, leprosos, prostitutas, vagabundos e pedintes (VAUCHEZ, 1985, p. 111).

Inquilinos em uma morada transitória, animados pela obsessão da salvação e pelo medo do inferno, à cabeceira da morte, homens e mulheres desprendiam-se de suas riquezas em nome da caridade. Indicativo segundo alguns do "despojamento de uma vida cúpida", perante outros de um desprezo que só evidencia uma paixão vivida em seus limites (LE Goff, 1983, p. 233; ArIÉs, 1981, p. 204), as doações aos pobres ou às obras assistenciais se tornaram um lugar comum nos testamentos da Idade Média.

Instrumento do direito privado entre os antigos, mas um ato religioso obediente aos preceitos da Igreja entre os medievais, suporte para redistribuição de fortunas aquinhoadas sobre os mesmos pobres, os testamentos acabaram por passar a limpo a rasura da riqueza e de um bem estar usufruído sem a culpa cristã. Embora não fossem poucos aqueles a doar uma fortuna que se limitava a um lençol, a uma coberta, a uma dádiva singela, o gesto da caridade era em vida, por excelência, um ato nobre; doutras vezes, um recurso para mesurar a salvação dos agentes do diabo nas "quedas" e "acelerações" do tempo de Deus.

Ao fundar hospitais, ao calçar, vestir e alimentar os excluídos, desprezados e marginalizados, os herdeiros de Eva e Adão construíram suportes para uma "esmola personalizada" (Mollat, 1989, p. 149). Pois, na verdade, na economia da caridade só dá aquele que possui mais do que precisa, só oferta aquele a quem excede. 
Numa luta por equivalências celestes, porque se sabia de velho que no reino dos céus os pobres encontravam morada cativa e que até o impossível era mais provável do que um rico assentar no paraíso de Deus, madrinhas da caridade como D. Isabel de Aragão (1271?-1336), esposa do rei D. Dinis de Portugal (1261-1325), tornaram-se veículos de uma solução pacífica (mantenedora da ordem) para os desarranjos sociais..

O traço caridoso que contorna a silhueta desta soberana marcou uma fórmula de atuação para a prima dona da corte régia: a fonte de comunicação entre o ápice e a base da sociedade, entre a realeza e os súditos. Conquanto, através de atos cristãos idealizados, tanto no ambiente dos que falavam um idioma germânico, como em meio aos que professavam uma língua latina, a ação feminina altruísta, comovida com a dor alheia, vincada pela virtude e pela fé, demarcou a atuação pública da senhora do paço.

\section{A Prima Dona e a Senhora Pobreza}

No dia de São João Baptista do ano de 1282, os portugueses testemunharam, na cidade de Trancoso, as bodas do rei D. Dinis com D. Isabel de Aragão. O consórcio que selou a união entre o sexto monarca da dinastia de Borgonha e a filha de D. Pedro III e D. Constança garantiu à Portugal, por certo, uma aliança de peso no âmbito das Hispânias. A princesa trazia com o seu nome a lembrança de ter nascido em uma casa nobre, abençoada pelas cicatrizes de seus guerreiros, valorosa por adicionar à sua crônica política vitórias sobre a resistência muçulmana e impor-se no comércio mediterrânico através das conquistas de Maiorca, Valência e Múrcia. Mas, se este saldo favorável parece inequívoco e consta dos panegíricos escritos em memória deste reinado, para a tradição oral, Portugal ganhou muito mais com estas núpcias: uma Rainha Santa. Uma mulher sensível às esferas invisíveis, uma dama de predicados marianos e como esta "advogada dos pobres".

Conta a Lend $a^{2}$ que a sorte da princesa foi anunciada ao mundo na hora de seu nascimento, pois em seu corpo de bebê trazia consigo a marca do empelicado. Era corrente nestes tempos crer que os nascituros envolvidos em uma pele tinham um dever, imposto pelo destino, de salvaguardar a prosperidade e a abundância. Segundo a crença popular, este sinal diferenciador era, na verdade, uma marca de distinção e 
poder. Não foram poucos aqueles a simular um episódio semelhante para se imporem diante de sua comunidade. ${ }^{3}$ Mas a memória popular assevera que D. Isabel não precisou de subterfúgios. Tanto que, sua mãe, comovida com o acontecido, abreviando as distâncias entre o palácio e as gentes do campo, revelando que a muralha entre o sistema de crenças de segmentos sociais distintos não era intransponível, guardou a membrana e "conservou em devoção enquanto viveu" (FigueiredQ, 1817, p. 107).

Carregando em seu nome a promessa "de ser consagrada à Deus" (GuÉrin, 1880, vol. 8, p. 33), a pequena Isabel mostrou-se desde cedo "avessa aos jogos e às recreações inúteis" (Idem, p. 107). Demonstrava uma afeição desmedida pelas coisas da fé, fazendo da oração e dos "exercícios angélicos" seus companheiros mais próximos. Diante destes atributos, seu avô, D. Jaime, o conquistador, assegurava a todos que haveria de ser a "melhor molher a sair daquele paço" e, para registrar seu carinho e admiração pela neta, cunhou-lhe um epíteto: $a$ Rosa da Casa de Aragão (ibid., p. 108).

A fama da princesa, garantem seus biógrafos, já havia corrido os reinos e, como muitas outras heroínas dos contos populares, já havia despertado a atenção de muitos cavaleiros. Entretanto, educada para tornar-se uma rainha, a jovem princesa só deixou sua parentela para ir ao encontro de uma terra estranha para casar-se com um rei. Assim, com onze anos de idade, ela ascendeu ao trono luso.

Como de costume nestes tempos, ela concluiu sua educação segundo os moldes da parentela que a recebeu. A nova morada insistiu, por certo, em sua docilidade e estimulou suas inclinações religiosas, seguindo a cartilha dos oratores e a orientação dos Evangelhos. Deste modo, continuou entregue aos "cilícios, às rezas e jejuns" (Afonso, 1560, p. 21) até que, apta para garantir a descendência à coroa, deu a luz à $D$. Constança e, quatro anos depois, ao varão Afonso, futuro monarca português.

Sabe-se que o longo reinado dionisino foi vincado por duas grandes guerras civis, que opuseram a nobreza senhorial nortenha às pretensões centralizadoras da dinastia de Borgonha, dividindo as certezas entre os membros da casa real. O primeiro destes sangrentos episódios apartou D. Dinis e seu irmão, o infante D. Afonso; o segundo, que separou o filho de D. Isabel de seu meio irmão e homônimo, assaltou a saúde d'el 
rei, embora tenha garantido para o bravo Afonso o direito de sentar-se ao trono e tenha asfixiado as faç̧ões contrárias à monarquia lusa.

A narrativa destes acontecimentos, porém, não contou apenas com atores masculinos. São muitas as vozes a destacar a atuação de D. Isabel neste cenário. Sua participação não se limitou apenas à emissão de cartas para chancelar os propósitos de seu senhor e marido, como também não se resumiu à concessão de pródigas quantias para financiar os rompantes de seu rebento contra o enteado (SANTOS, 1995, p. 142). A tradição popular fixou sua intervenção nestes tempos nebulosos com outro cariz: insistindo em seu papel medianeiro.

Como entre tantas outras passagens de sua Lenda, D. Isabel figura entre estes guerreiros como uma soberana capaz de interferir no mundo dos homens com poderes sobre-humanos. Segundo essa criação popular, em meio a um daqueles episódios sangrentos, a mãe de D. Afonso vendo-o "muy sanhudo", irado com os favores que o pai cumulava ao bastardo Afonso Sanches, e temendo que seu confronto direto com D. Dinis fosse inevitável, precipitou-se, sobre uma mula, em meio ao campo de batalha a fim de conter os ânimos (LA FigANiÉRE, 1859, p. 170).

A paz, que a memória popular e os panegíricos compostos em sua memória celebram como um milagre, destaca seu perfil santo e sua nata vocação para tecer alianças e abrandar os espíritos. Afinal, nada mais se esperava senão um fim trágico.

A despeito do lugar que esse feito ocupa na memória portuguesa, é decerto $O$ Milagre das Rosas ${ }^{4}$ o mais popular de todos os relatos hagiográficos que cercam a vida da rainha D. Isabel. À semelhança da narrativa de feição franciscana que traz esta personagem política em uma montaria comum entre os mais humildes e onde se mostra capaz de serenar o ódio dos pares do rei, esta também persiste na oposição entre aqueles que desposaram a Senhora Pobreza e aqueles fiéis às conquistas materiais.

Assim, conta-se que certo dia, quando caminhava em direção aos portões do paço para distribuir donativos aos pobres, a Rosa da Casa de Aragão foi surpreendida pela chegada abrupta de D. Dinis que, instigado por um certo cavaleiro privado, temia que a rainha estivesse a esboroar os bens da coroa ao distribuir esmolas entre os desafortunados. Interrogada com certa arrogância pelo monarca que insistia em saber o que ocultava em seu regaço, a rainha não se intimidou. Respondeu-lhe 
que se tratavam de rosas. Caçoando da dama, seu senhor e marido perguntou-lhe como tal "cousa" era possível pois "não havia rosas nem sequer maravilhas em janeiro". A rainha, então, abriu-lhe as vestes e em rosas se transformaram o pão e o dinheiro.

Este milagre registrado no Cancioneiro de Coimbra ${ }^{5}$, que recebeu estrofes ritmadas dos jograis da Península e também integra o dossiê de outras santas, inclusive o de sua tia-avó, incompatibiliza, como aquele primeiro, rei e rainha e, ainda, o que ambos representam.

Caro ao imaginário franciscano, ao maravilhoso hagiográfico, inscrito no seio das crenças populares, a transformação do pão em rosas operada por uma figura feminina de silhueta altruísta, é um dos ícones da caridade cristã medieval e remete à uma estrutura ficcional que faz dos milagres verdadeiros documentos sociológicos. ${ }^{6}$

Note-se que os dois argumentos antagonizam D. Isabel e D. Dinis. Tanto num quanto noutro, os pais de D. Constança estão em margens opostas. Primeiramente, el rei, à frente de seus cavaleiros-vilões, inchado de orgulho, apresenta-se ávido pelo fracasso das hostes inimigas e pela manutenção de sua autoridade, enquanto $\mathrm{D}$. Isabel, parece despirse de sua condição de rainha ao mostrar-se perante todos como a mais humilde de suas súditas. Só a ausência de soberba parece-lhe necessário para governar o destino dos portugueses. A seguir, a proteção e o cuidado que dispensa aos mais necessitados, como "advogada dos pobres", a indispõe com o monarca, que se mostra um sovina e uma presa fácil das intrigas palacianas, mas que acaba ridicularizado por suspeitar de uma rainha tão virtuosa.

A arquitetura ficcional dessa composição, perenizada pela tradição oral, repete-se também no Milagre do Pobre na Alcova? , onde a soberana é mais uma vez vítima de insinuações caluniosas. Provocado por outro mexerico, D. Dinis acorre aos aposentos de D. Isabel suspeitando de que ela se encontra com um amante. Ao adentrar na alcova, surpreende-se ao vê-la cuidando de um pobre. Aproximando-se do infeliz, ajoelha-se a seus pés pois descobre que se tratava do próprio Cristo.

Como naquele outro, as ações do rei lavrador são diametralmente opostas àquelas protagonizadas pela Rainha Santa. Mas o conflito presente nestes enredos, que distingue a silhueta de uma soberana afeita aos motivos de edificação religiosa e benfeitora dos pobres, do perfil de 
um monarca guerreiro, entregue às delícias da corte e pai de inúmeros bastardos, constituiu, na verdade, um equilíbrio de forças no interior da coroa portuguesa e marcou a atuação na esfera pública das figuras feminina e masculina.

Pode-se afirmar, com efeito, que a forma assumida por este casal governante fez escola por dar corpo ao discurso médico, trovadoresco e religioso e por abreviar as distâncias entre os vários segmentos que compunham a sociedade medieval portuguesa. De "natureza viril e colérica" (Thomasset, 1993, p. 65), pai de inúmeros bastardos, D. Dinis era um guerreiro, um enamorado da arte trovadoresca que promovia, nos salões do paço, querelas jogralescas entre seus cavaleiros. Cabe dizer, um verdadeiro representante da nobreza de corte. Mais próxima da virtude e da fé, "fleumática e melancólica", adepta das práticas de autoflagelação e amante das peregrinações, quase uma asceta, não fosse a obediência que o casamento lhe impunha, D. Isabel estava próxima das coisas de Deus. Deste modo, satisfazia as exigências espirituais de seu tempo, aproximando-se do clero e do povo humilde sem pão e sem brasão,

A forma da primeira dama do paço respondia, desta feita, a um enorme apelo popular. Conjugava a prédica mendicante às adjetivações marianas. Descrita no repertório de canções e lendas populares como uma Rainha Santa, a personagem política Isabel de Aragão emergiu de uma sociedade onde o fosso a separar ricos e pobres, senhores e camponeses, bispos e humildes prelados era intransponível. Não obstante, seria ingênuo supor que esta forma de soberana fosse obra apenas da cultura folclórica.

Sabe-se que o próprio D. Dinis, com linhas definidas e tintas fortes, ordenou que a imagem de sua esposa e de seu filho legítimo fosse superposta à imagem da Virgem e do menino Jesus, na Capela dos Três Reis Magos na Sé de São Domingos (SouzA, 1866, p. 399). Logo, a associação entre a Rainha Santa e Santa Rainha foi também uma obra do paço. Nem um poder, senão o régio, seria capaz de tal feito. Caso contrário, seria uma profanação à imagem da rainha e um sacrilégio com a personagem bíblica. A inversão dos epítetos, certamente, também não é mera coincidência. Nesses dias, o culto à Virgem, expresso nas inúmeras ermidas erguidas em sua devoção, alimentava a construção de 
uma imagem feminina idealizada, que serviu de base para a silhueta das rainhas na cultura cristã medieval (SANTOS, op. cit., p. 123).

Como um bom governante, D. Dinis dirigiu a cena política com ciência e perspicácia. "Comandou o real através do imaginário" (BALANDier, 1982, p. 6), cunhando para seu reinado uma estampa personalizada da Mãe da Cristandade: unificadora, capaz de volatear as tensões sociais.

Em uma conjuntura encrespada, enrugada por projetos políticos contrários ao paço, uma imagem exclusivamente belicosa significava também uma existência constantemente ameaçada. Desta feita, el rei distinguiu-se dos demais nobres por uma união santa, mas também acalentou os preceitos da fé com uma rainha caridosa e confortou os " mantenedores" com uma figura maternal.

O casamento entre o poder temporal e a caridade não se operou, entretanto, apenas no terreno das representações coletivas. D. Isabel colou-se à memória popular por ser parte integrante do projeto político dionisino, que concedeu um lugar à caridade através da senhora do paço.

\section{A Protetor e Governador}

À maneira de suas antepassadas da Alta Idade Média, a rainha verteu seus esforços de mulher madura ${ }^{8}$ para o convívio com as coisas de Deus. Aos cinqüenta e cinco anos, exibindo saúde após duas gestações felizes ${ }^{9}$, já dispensada da tarefa de procriar, ela foi convidada pela lei dos homens a viver seu luto na castidade em respeito a caritas, e por conseguinte, ao fantasma de seu rei e marido.

Nos Helisabeth dei gratia regina Portugalie et Algarbii [...] Si uero prefatum domnum maritum nostrum premori quod absit et post ipsum uiuere nos contingat volumus proponimus et intendimus predictas uestem et cordulam ac uellum viduytatis licet instar habeat ordinis [...] nom in habitum religiosum probatorium uel professorium [...] sed solum causa et in signum viduitatis et humiliatis [...] et alias quascumque seculares et laycales quas nobis competre uiderimus et uoluerimus assumere et induere et de nostris rebus bonis iuribus et persona disponere et facere libere uelle nostrum. ${ }^{10}$ 
Firmada em 2 de janeiro de 1325, às vésperas do passamento de D. Dinis, seguindo a etiqueta dos oratores, com um selo de cera vermelha pendente a uma fita de lã verde - justo com as cores que no futuro tingiriam a flâmula lusa - D. Isabel declarou sua intenção em apresentarse como as vestes de clarissa. Resguardando aos laicos e seculares o dever de seguir a sua sombra, este ornamento externo cabível à santidade da irmã lua era o sinal de uma viuvez humilde e honrada. A rainha, porém, subtrai deste intento a emissão de voto, profissão ou qualquer sujeição à Ordem.

Dispondo dos bens acumulados à época em que era titular da casa da rainha, a viúva de D. Dinis eximiu-se em fazer uma entrega sem limites à vida franciscana, por temer qualquer fenda para disputa entre as ordens religiosas e seus herdeiros legítimos ou mesmo entre os profissionais da fé católica.

Durante seu reinado, ainda menina, em face do consórcio que a levou ao trono português, D. Dinis já lhe havia outorgado termos, rendas e direitos sobre Óbidos, Abrantes e Porto de Mós. Embora registrada pela primeira vez sobre uma ocasião solene, esta prática não se reduziu a eventos festivos. O mesmo rei retratado como um sovina nas cantigas populares foi, neste aspecto, bastante generoso com a mulher. Mas, certamente, não por uma paixão desmedida.

Como um recurso para manter sob a guarda da coroa pontos estratégicos de defesa e comércio, o monarca ofertou-lhe também outros senhorios. Assim, somaram-se às posses de D. Isabel, as vilas de Sintra, na Estremadura - doada pela Ordem do Templo e posteriormente cedida ao cunhado - além de Trancoso, na Beira Alta. Sua fortuna acressceu-se ainda com a Quinta de Fandega da Fé, próximo a Torres Vedras, e com a vila de Leiria, sua herdade mais distinta pois, ao contrário das demais em que a alcaidaria estava sob os cuidados d'el rei, a rainha foi de fato a senor desta terra."

As aquisições da soberana foram engrossadas também com as inquirições reais, com a intervenção régia na sucessão dos direitos sobre a propriedade. Deste modo, por infelicidade dos herdeiros de um dama do séquito de sua sogra, D. Beatriz de Gusmão, e para felicidade da monarquia, disposta a asfixiar heranças ilegítimas, D. Isabel recebeu das mãos de seu senhor e marido Atouguia, dilatando suas terras nos limites de Óbidos. 
El rei sabia o quanto era importante ter sob sua vista as duas regiões mais populares do país, o caminho onde o ir e vir concentrava trocas e contatos comerciais, onde a organização social e econômica dos concelhos e dos senhorios se fazia representar. ${ }^{12}$ Desta feita, as residências da Estremadura, próximas às herdades da rainha, foram cenários onde a primeira entre todas as senhoras interveio no rumo dos acontecimentos régios.

Sob o teto das salas do paço de Coimbra, D. Isabel emitiu juízos, selou compromissos. Mas foi no paço de Santarém que a "melhor molher sair da casa de Aragão" despediu-se da vida de casada e viu o pai de seus filhos, o rei de Portugal, fechar os olhos. Nele, deu as costas aos adornos de rainha para vestir-se como as mulheres pias em devoção à Senhora Pobreza.

A contar que os frades menores acorriam para os cantos em que o volume da população citadina era um ninho de almas carentes da Boa Nova e do pão de cada dia, fossem gentes sem um mentor paroquial, fossem migrantes desligados do sistema senhorial, D. Isabel como simpática à pedagogia da Ordem Terceira poderia ter escolhido Óbidos, Torres Vedras ou mesmo Santarém, a primeira entre as mais freqüentadas do período (MATTOSO, 1992, p. 330). Não obstante, com a morte d'el rei a soberana fixou sua residência em Coimbra, álbum de sua juventude, onde segundo a Lenda, pôs a concluir as obras do convento de Santa Clara. $^{13}$

Ao contrário das fundações franciscanas masculinas- isentas de imposições fiscais, civis e eclesiásticas - sempre atraídas pela marcha do desenvolvimento urbano, e, por isso mesmo, distantes das regiões vincadas pelo regime senhorial, os conventos femininos foram adotados pela alta nobreza ou pela família régia e eram indiferentes à escolha do meio rural ou urbano (ibid, p. 344).

Assim, por saber da envergadura de seu dote, a Rosa compôs uma saída diplomática, pacificadora e atenta às regras sociais: salvaguardou os direitos do filho, o rei D. Afonso IV, mas adocicou o paladar do clero com doações vultuosas e obras de assistência, purificando sua riqueza como uma nobre mulher medieval que aguarda a morte.

Foi, portanto, no abrigo dos edifícios que ajudou a erguer ainda à época dionisina, na comunidade religiosa da qual se dizia padroeira $e$ provedor, padroeira e governador que D. Isabel encostou sua velhice. 
Apesar de um considerável montante em terras e de um tesouro em jóias e coroas nada desprezível, D. Isabel não foi tomada pela tradição nem como aleivosa, nem como leviana, tampouco como avarenta. Espelhando-se nas virtudes teologais paulinas, entre os muros de sua nova morada, ela deu voz ao "Hino da Caridade", ensaiou diariamente seus gestos, refinando o papel de rainha e atestando para a posteridade a sua máxima: "a caridade jamais passará" (13, Cor. 1-13).

\section{Ave Misericórdia!}

Levantado do chão com a proteção santa de sua tia avó e homônima, repleto de altares, com um cemitério e um hospital, este novo paço era uma casa de acolhimento. Nele, a pele castigada pelo infortúnio da lepra constituía o caminho para privar da companhia das moças, o estômago inerte há dias era o distintivo para cear entre os demais, a iminência da morte, a certeza de uma recepção calorosa. Nesta corte, distante da vaidade, onde o orgulho e a virilidade cavalheiresca estavam ausentes, onde os versos do trovador não eram ouvidos, a tristeza sentida valia mais do que a alegria ostensiva.

Suporte para a economia da caridade, espaço-vitrine onde o vivido interceptava o imaginário, o novo lar de D. Isabel era um castelo onde a tríade paulina recebeu quadro e moldura. Longe do passado, da corte dionisina, das intrigas de um certo cavaleiro privado, que teimava em delatar ao rei suas pródigas esmolas, ela estava livre para abraçar as três graças da caridade. Conta a tradição que

ella vestia nus, e aos que hauião fame ou sede mandaualhes acorrer com comer e beuer. E o enfermo vistaua, e fazia visitar. E os mortos fazia enterrar e thes daua pera sepulturas o que mister hauião; por os apressados pagaua; e corregia os que em perdiçom estauão. Conselhaua pera perseuerarem. Em ella mantinha a espiritualidade: remia catiuos pagando por elles do seu hauer, a outros dando ajuda para se remirem. ${ }^{14}$

A Lenda recorda o quanto era prestativa, pois atendia a todos que the pediam "merce", fossem "pobres" ou "ricos", "religiosas", observantes da fé cristã, ou "segraes", servidoras da luxúria. Sem orgulho, 
perdoava "o rancor e a "satisfaçom", paciente como por "maravilha, "nunca [estava] sanhada". Is

Personifícação da prosa paulina, de uma imagem assistencialista, D. Isabel saudou a misericórdia muito antes desta tornar-se um substantivo próprio em terras portuguesas [!]. Feitos para atravessar os séculos, como todo lugar de memória, o paço e o "Espital de ssanta Helisabet" receberam, assim como tantas outras casas religiosas, a especial atenção da rainha, em seus testamentos.

Revelando uma política de doações sustentada sobre as intenções régias, o primeiro dos testamentos da rainha data de 1314 e tem como um dos testamenteiros o próprio rei. Cautelosa com o destino de sua alma no além-túmulo, D. Isabel apressou-se em prescrever com exatidão as etapas e os cuidados necessários para seu rito fúnebre. Tendo escolhido para seu jazigo perpétuo o mosteiro de Alcobaça, "a so os degraos dante o altar maior ali hu se El rey manda [ou] soterrar"16, D. Isabel destaca que a cerimônia do adeus deveria se realizar com "as melhores vestimentas", junto à "crux de ouro", com todos os ornamentos que houvesse na capela. Para tanto, a testante lega aos referidos monges a quantia de três mil libras para que fossem comprados herdamentos mas, "com a condiçom" que dois "capellaes" the cantassem "duas missas a cada dia pera sempre" [!].

Ícone da compreensão do ato de testar como uma maneira de redimir pecados pretéritos mediante um instrumento público, da autoridade eclesiástica como o único veículo capaz de mediar a oferta da salvação, o testamento da rainha, semelhante em teor e temor a outros nos séculos XIII e XIV, atesta a "clericalização da morte" (ArIÉs, 1981, p. 195).

Tal e qual muitos de seus contemporâneos, D. Isabel também mandou erigir uma capela, com cálices e outros apetrechos, que daria lugar a duas missas diárias patrocinadas com sua oferta. Note-se, porém, que sem pudor a soberana condiciona a doação à Ordem ao cumprimento de seu desejo. O mesmo movimento se repete nos itens referentes à Santa Misericórdia de Rocamador, a quem enviou "hum cálix e vestimenta boa" para que "canta[sse] um clérigo" e às doações ao mosteiro de Odivellas, que receberiam duas mil libras para que orassem a cada dia em prol de sua alma.

D. Isabel tencionava, porém, doar sem exigências ulteriores. Embora suas camareiras, "homens de pee" (vassalos) tenham sido 
contemplados e em se tratando de seus parentes mais próximos com os símbolos de seu poder temporal, isto é, com sua coroa, os mais beneficiados nesta carta de intenções foram as fundações religiosas, as albergarias, as enfermarias e os pobres. Sublinha-se, porém, que estas doações pro anima não concorrem nem de longe com as ordens religiosas responsáveis por seus restos mortais ou pelos ofícios litúrgicos que deveriam marcar o seu "lugar de memória" (SANTOS, op. cit, p. 200).

Pode-se dizer então que, diante da morte, a necessidade de acertar as contas com a Providência divina era "um contrato de segurança concluído entre o indivíduo mortal e Deus, por intermédio da Igreja", ou mesmo um "salvo-conduto" para que o prazer durante a vida não fosse um fato suspeito (Ariés, 1981, p. 203). Contudo, em se tratando da realeza, a prodigalidade deveria submeter-se à eternidade e, portanto, era mister lembrar aos súditos que a monarquia era capaz de protegê-los das intempéries e dissabores da vida. O segundo testamento da rainha ratifica esse propósito, salientando a caridade como receita para bem governar e evitar contratempos capazes de rasurar a memória de uma dinastia.

Prescrita na semana do natal de 1327 , quando D. Isabel estava prestes a completar três anos de viuvez, a nova versão de suas pretensões na alcova da morte, lavrada em Estremoz, manteve as características do documento original. ${ }^{17}$ Mais uma vez, os hospitais, os "frades menores", as "emparedeadas" e demais monastérios, bem como, os "pobres", "cativos" e "gafos" foram beneficiados. Todavia, catorze anos depois, a distribuição do montante privilegia outras ordens religiosas, particularmente as Clarissas de Coimbra, que recebem, em contrapartida às quinhentas libras da primeira versão, doze mil libras, enquanto Alcobaça é dotada apenas com 100 libras "pera pitança"18 e Odivellas vê sua oferta minorada para a quantia de 1000 libras, certamente porque perderam a primazia de guardar os restos mortais da rainha. Note-se que aqui, D. Isabel absteve-se de lembrar o número de missas e a importância dos capelães, deixando à guarda da abadessa, decerto já previamente informada, o comando do cerimonial fúnebre.

Este remanejamento de dotes para um ou outro mosteiro seguiu, por certo, o sabor das conjunturas. Observa-se que os rendimentos da nobre viúva praticamente duplicaram entre uma e outra carta de adeus. Um indício de que as inquirições engordaram os bens da soberana? Provavelmente. No entanto, pode-se também supor que tendo sido seu 
testamenteiro em 1314, D. Dinis tenha se ocupado para que suas posses não migrassem desmedidamente para as mãos do clero. Quer por uma ou outra razão, a imagem popular de um rei "sovina" e "cobiçoso" evoca aqui a sua presença.

Se a autoridade do monarca inibiu de algum modo os arroubos altruístas de D. Isabel, aquelas doações coletivas em que não se identifica o destinatário a não ser pelo sofrimento mantiveram-se ilesas. A repartição da fortuna entre estes marginalizados não the causou hesitação nem numa nem noutra versão.

No codicilo de 12 de março de 1328, quase um ano após o segundo testamento, D. Isabel prescreveu um conjunto de doações à fundação de Santa Clara antevendo suas necessidades como uma casa de atendimento aos pobres. Neste último documento, espécie de parágrafo aberto sobre as intenções de sua última carta de adeus, D. Isabel lega a direção do estabelecimento à abadessa das clarissas ou à "outra pessoa ydonea", escolhida pela casa real, e revela os procedimentos a serem utilizados para o gerenciamento desta corte de miseráveis. Com efeito, o hospital deveria atender apenas aos pobres das imediações do convento e "nenhuma pessoa, nenumaa mays longe", exceto com aprovação da superiora. ${ }^{19}$

O rigor da Rainha Santa em impor limites à caridade não se restringiu à rejeição de forasteiros, sustentando-se, sobretudo, na qualidade, número e idade dos pobres a serem socorridos pelo hospital. Comungando do discurso de seu falecido esposo que protegia apenas aos tinhosos, cegos, velhos, fracos e viúvas (FERro, 1989, p. 36), D. Isabel agraciava somente aos "homeens" e às "molheres pobres de uergonha"; os únicos dignos de habitar sua corte de moribundos. Sinal de que a mendicância crescia e se profissionalizava? Muito provavelmente. Nota-se, portanto, que nem todos eram tomados com "bem-aventurados".

Na tentativa de evitar parasitas com disposição e força para o trabalho, de impedir a deserção dos campos com ondas migratórias, uma triagem julgava estas gentes pela aparência de seus corpos à entrada do hospital. Como revela a mesma fonte, aqueles com idade avançada eram chamados a partilhar de "huma tagara de vinho", de "duas onças de pam cozido", de "dous arataes de carneyro, porco ou vaca", que as damas muy pias desta enfermaria ofereciam. 
Sendo uma simples casa de acolhimento, um espaço para morrer, esta dieta, quiçá suculenta aos olhos dos desvalidos, acenava timidamente para um recuperação física. Certamente menos dispendiosos, aqueles com "cinquoeenta anos ou mays", privilegiados na seleção da protetor e governador, podiam utilizar o abrigo como morada. Contudo, este acolhimento acabava por se tornar um asilo temporário, haja visto a idade com a qual adentravam em seus portões. Logo, pode-se supor que a rotatividade entre o paço e a rua era alta, quando se tem em mente que a média de vida dos homens e mulheres sexagenários era baixa nesta temporalidade.

Eis porque, em outro item do codicilo, D. Isabel ordena que "no dito Espital [houvesse] capelam e moozynho" para celebrarem missas e as horas canônicas. O que fariam estes personagens, distintos dos poetas da corte régia, imbuídos da tarefa de divertit, senão consolar com orações e atenuar a espera de uma hora derradeira e inevitável?

Reconhecidos pela "solidão, velhice e doença", escravos muitas vezes de uma marca social diferenciadora, incapacitados para o trabalho pela cegueira ou paralisia, com a cidadania capturada pela lepra ${ }^{20}$, estes tipos comuns nas cidades medievais eram vítimas de uma perversidade que encontra suas raízes nas impossibilidades médicas do período. Mas sobretudo na perversidade dos estigmas sociais, nas discrepâncias de uma era onde o dinheiro já fazia as honras do bem-estar. Entretanto, estas figuras foram veículos para o exercício dos poderes religioso e monárquico, foram peças fundamentais na construção de personalidades de sucesso, como D. Isabel de Aragão, eleita protetora e defensora de toda a nação portuguesa em 1556 e canonizada em 1625.

Conclui-se, portanto, que o amadurecimento das instituições de assistência ao longo dos últimos séculos da Idade Média portuguesa confunde-se com o processo de afirmação da própria monarquia. $\mathrm{Na}$ verdade, é parte integrante de sua concepção, quer por eliminar do horizonte político a sedição, quer por dialogar com o imaginário. Visto que, na Idade Média, o "político é uma província do religioso" (LE Goff, 1985 , p. 229) e a própria santidade, baseada nos gestos de piedade e devoção, um elemento estruturante da feição do governante, pode-se afirmar que a caridade é também um eixo por onde gravita a consolidação do poder régio medieval e mais, do próprio conceito de Estado no Ocidente Cristão. 


\begin{abstract}
The late Portuguese Middle Ages gave to charity a great role in the process of the afirmation of the royal power. Based on the marian female model and on the mendicant's discourse, the queen Elizabeth's actions were able to eliminate the social distances. Then, she had been transformed in a saint by the oral tradition. This queen's pattern established a role for the first lady in the Portuguese political imaginary.
\end{abstract}

Key-words: Portugal; queen; charity.

\title{
Notas
}

1. "Agora, portanto, permanecem em fé, esperança, caridade, estas três coisas. A maior delas, porém, é a caridade" (13, Cor, 13-13).

2. A Lenda da Rainha Santa é de autor desconhecido e tornou-se popular logo após a morte da soberana. (LA Figaniére, 1859, p. 257)

3. Carlo Ginzburg demonstra que entre os benandanti, certas mulheres propagaram enganosamente um nascimento similar, já que esta era a condição sine qua non para o diálogo com os mortos.(GINZBURG, 1988. p. 65, 87, 90)

4. "Estoria da Rainha Santa" (VIEIRA, 1918, p. 125).

5. Os mais antigos textos literários em língua portuguesa são composições em verso reunidas em Cancioneiros em fins da centúria do XIII e do XIV, outras chegam a remontar ao século XII. (Cf. Saraiva \& Lopes, 1982) Se na arte nenhuma linguagem é neutra, em seus suportes de representação coexistem vestígios de objetividade e expressão (Ostrower, 1988, p. 175). Por isso, os Cancioneiros são verdadeiras minas de imagens que obedecem à estrutura de pensamento medieval.

6. Este milagre integra as vidas de Santa Rosalina, Santa Isabel de Hungria e Santa Rosa de Viterbo, as duas últimas foram membros da Ordem Terceira. (SANTOS, 1995, p. 126)

7. "Milagre do Pobre na Alcova" (VIEIRA, op. cit., p. 126);

8. A longevidade não era um atributo dos reis e rainhas da Idade Média. Os primeiros faleciam em média antes dos cinqüenta anos e as soberanas antes de completar a quarta década. Num tempo em que a morte saudava cedo os seres viventes, em que "o sentimento de finitude" era uma realidade, D. Isabel e seu cônjuge figuraram como exceções. O lavrador esteve à testa do governo durante quarenta e seis anos e faleceu como um sexagenário. (MatToso, 1993, p. 359).

9. A principal causa mortis entre as mulheres medievais era o parto, seguida em ordem decrescente de importância pelo aborto, além das fomes e epidemias (Oprtz, 1993, p. 360). 
10. Declaração feita pela rainha D. Isabel de querer ser sepultada com o hábito de Santa Clara, no mosteiro desta santa em Coimbra. No caso de sobreviver a seu marido, quer, por morte de D. Diniz, vestir o sobredito hábito (VASCONCELLOS, 1894, vol. 2, p. 8).

11. D. Isabel usou e abusou destas prerrogativas por ocasião da guerra civil que opôs D. Dinis a seu filho D. Afonso IV (SANtos, 1995, p. 142).

12. A configuração do itinerário de D. Dinis revela uma movimentação intensa de sul a norte do país, particularmente, na via litoral que liga a Estremadura ao Entre Douro e Minho (MatToso, 1988. p. 245).

13. A fundação do primeiro convento de Clarissas em Coimbra teve como protagonista a gorda fortuna de D. Mor Dias, falecida em 2 de janeiro de 1302. Cinco anos depois, D. Isabel apadrinhou a idéia de continuar esta obra pia (LA FigAnIÉRE, op.cit, p. 187).

14. Lenda da Rainha Santa (LA FiganiÉRe, op. cit. p. 300).

15. "A caridade é paciente, a caridade é prestativa, não é invejosa, não se incha de orgulho [...] tudo desculpa, tudo crê, tudo suporta (1 Cor. 13-14).

16. Primeiro Testamento de D. Isabel de Aragão, rainha de Portugal, esposa d'el rei D. Diniz (Vasconcellos, 1894, vol. 2, p. 6).

17. Segundo Testamento da Rainha D. Isabel (LA Figaniére, op. cit. p. 283).

18. Refeição monástica (NASCENTE, 1955, tomo 1, p. 402).

19. Codicillo da rainha D. Isabel, feito $\mathrm{em}$ forma de doação, depois do testamento precedente (LA FIGANIÉRE, op. cit., p. 292).

20. A exclusão formal da sociedade privava o leproso de seus direitos civis, que era impedido de legar ou herdar propriedade e de defender suas demandas no tribunal. No entanto, a Igreja reiterava que a lepra não era motivo para a dissolução do casamento. O custeio de hospitais de leprosos cra visto como uma notável atitude de caridade (RICHARDS, 1993, p. 159).

\section{Fontes impressas}

A Bíblia de Jerusalém. São Paulo: Paulinas, 1991.

Afonso, Diogo. Vida e Milagres da Gloriosa Raynha Sancta Ysabel, Molher do Catholico Rey Dó Dinis Sexto de Portugal. Com ho Compromisso da Confraria do Seu Nome \& Graças a Ella Concedidas. Coimbra: 1560.

Codicillo da Rainha D. Isabel. In: LA Figaniére, Frederico Francisco de. Memórias das Rainhas de Portugal. Lisboa: Typographia Universal, 1859.

Declaração feita pela rainha D. Isabel de querer ser sepultada com o hábito de Santa Clara, no mosteiro d' esta santa em Coimbra. No caso de sobreviver a 
seu marido, quer por morte de D. Diniz vestir o sobredito hábito. in: Vasconcellos, Antonio Garcia Ribeiro de. Evolução do Culto de Dona Isabel de Aragão, esposa do rei lavrador Dom Dinis de Portugal (a Rainha Santa). Coimbra: Imprensa da Universidade, 1894. Vol. 2.

Lenda da Rainha Santa. In: LA Figaniére, Frederico Francisco. Op. cit.

Primeiro Testamento de D. Isabel de Aragão, rainha de Portugal, esposa d'el rei D. Diniz, 1314. In: Vasconcellos, Antonio Garcia Ribeiro de. Op. cit.

Segundo Testamento da Rainha D. Isabel, 1327 in: LA Figaniére, Frederico Francisco de. Op. cit.

VieIra, A fonso. "Estoria da Rainha Santa" \& "Milagre do Pobre na Alcova". In: Cancioneiro de Coimbra. Coimbra: França Amado Editor \& Impressor, 1918.

\section{Referências Bibliográficas}

Ariés, Philippe. O Homem diante da Morte. Rio de Janeiro: Francisco Alves. 1981.

Balandier, Georges. O Poder em cena. Brasília: EDUNB, 1982.

Ferro, Maria José Pimenta. Pobreza e morte em Portugal na Idade Média. Lisboa: Presença, 1989.

Figueiredo, Pedro José de. Retratos e Elogios dos Varões e Damas que Ilustram a nação Portuguesa. Lisboa: Oficina de Simão Thaddeo Ferreira, 1817.

Ginzburg, Carlo. Os Andarilhos do Bem. São Paulo: Companhia das Letras, 1987.

Guérin, Paul. Les Petits Bollandistes - Vie de Sants de L'Ancien et Noveau Testament. Paris: Bloud et Barral, 1880.

La Figaniére, Frederico Francisco de. Memória das Rainhas de Portugal. Lisboa: Typographia Universal, 1859.

Le Goff, Jacques. Para um novo conceito de Idade Média. Lisboa: Estampa, 1980.

. A Civilização do Ocidente Medieval. Lisboa: Estampa, 1983.

. O Maravilhoso e o Quotidiano no Ocidente Medieval. Lisboa: Edições 70,1985 .

. A Bolsa e a Vida. São Paulo: Brasiliense, 1989.

Matroso, José. A Identificação de um País. Lisboa: Imprensa Nacional, 1988. 2 vols.

.Portugal Medieval - Novas Interpretações. Lisboa: Imprensa NacionalCasa da Moeda, 1992. 
Mollat, Michel. Os Pobres na Idade Média. Rio de Janeiro: Campus, 1989.

Nascentes, Antenor. Dicionário Etimológico da Lingua Portuguesa, 1955. Rio de Janeiro: Francisco Alves. Tomos I e II.

OpItZ, Claudia. "O quotidiano da mulher no final da Idade Média" in KLAPISCHZuber, Christiane.(org) História das Mulheres - a Idade Média. Porto: Afrontamento, 1993.p. 353-435

Ostrower, Fayga. "A construção do olhar" in: Novaes, Adauto (Org) O Olhar. São Paulo: Companhia das Letras, 1988. p. 167-181.

Richards, Jeffrey. Sexo, Desvio e Danação - as minorias na Idade Média. Rio de Janeiro: Jorge Zahar. 1993.

Santos, Georgina. A Senhora do Paço - o papel da rainha na construção da identidade nacional portuguesa. Niterói, 1995. Dissertação de Mestrado Universidade Federal Fluminense.

Saratva, António \& Lopes, Óscar. História da Literatura Portuguesa. Porto: Porto Editora, 1982.

SouzA, Armindo. "Condicionamentos Básicos (1325-1480). In: Mattoso, José (Org.). História de Portugal - a Monarquia Feudal. Lisboa: Estampa, 1993. p. 311-389.

SouzA, Fr. Luís de. "De outras confrarias que há nesta Igreja, e de sua antigüidade, e devoção" in: História de São Domingos - Parte I. Lisboa: Typographia Panorama, 1866.

Thomasset, Claude. "Da natureza Feminina". In: KlaPISCh-Zuber, Christiane. História das Mulheres - a Idade Média. Porto: Afrontamento, 1993 p. 65-97

VAuChez, André. La Espiritualidad del Occidente Medieval. Madrid: Cátedra, 1985. 